\title{
10 Reshoring in the US and Europe
}

\author{
Steffen Kinkel, Diletta Pegoraro and Rosemary Coates
}

\subsection{Introduction}

The reshoring phenomenon in both the European Union (EU) and the United States (US) is a 'hot' topic as Industry 4.0 is shortening global value chains (GVCs) and new players from emerging markets are aggressively entering the global arena. Securing a strong and competitive industrial base is a focal requisite for advanced economies to remain competitive in today's business environment. This chapter provides evidence of the reshoring phenomenon in the EU and the US. Motives and challenges will be highlighted as well as the role of policy makers in supporting a possible reshoring strategy.

At first glance, we can say that reshoring in the EU is not so relevant, but it is an interesting phenomenon to take into account for revitalizing or for maintaining competitiveness in important industrial zones. In contrast, reshoring in the US is a predominant topic for policy makers, with arguments focused on bringing back jobs to the US.

After an overview section which compares the EU and US contexts, three selected European regions, namely Veneto in Italy, Baden-Württemberg in Germany and the West Midlands in the United Kingdom UK), are presented by way of exploring whether a reshoring strategy is a viable solution for sustainable competitiveness or not. Section 10.7 presents evidence on reshoring in the US, with three criteria highlighted to be considered in adopting a reshoring strategy. Finally, the conclusion presents an overarching list of motives that are driving reshoring decisions in both the EU and the US.

\subsection{Reshoring trends from data in the EU and the US}

Based on a rich literature review, we have analysed and compared empirical evidence that quantitatively measures reshoring activities in the EU, in selected single European countries and in the US (Kinkel et al., 2017). The following studies have been included:

- The 2012 Eurostat international sourcing survey (Rikama et al., 2013).

- The Uni-CLUB MoRe reshoring dataset (complied by the Italian Universities of Catania, L'Aquila, Udine and Bologna; e.g. Ancarani et al., 
2015; Fratocchi et al., 2014, 2016; Wan et al., 2017) and the subsequent European Monitor of Reshoring (EMR) (e.g. Ancarani et al., 2017), a collaboration between the EU Eurofound and the Italian CLUB Universities, based on a keyword search in secondary data of the major business-related newspapers, magazines and reports, white papers of major consulting companies and an internet search.

- Studies on European companies' backshoring activities, based on data from the European Manufacturing Survey (EMS) (e.g. Dachs and Kinkel, 2013; Dachs and Zanker, 2014).

- Longitudinal evidence on offshoring and backshoring activities in the German manufacturing industry (e.g. Kinkel et al., 2017; Kinkel, 2014; Kinkel 2012; Kinkel and Maloca, 2009).

- An online survey of buyers and purchasing managers from companies located in France and Western Europe (Fel and Griette, 2016).

- Results of surveys of UK-based manufacturers (Li et al., 2017; Bailey and De Propris, 2014).

- A comprehensive study on the 'Relocation of Nordic Manufacturing' in the Nordic countries of Denmark, Finland and Sweden (Heikkilä, 2017).

- The 2011 Boston Consulting Group report 'Made in America again’ and related follow-up work (Boston Consulting Group, 2011, 2012).

Based on these sources, we have drawn conclusions on evidence of reshoring in the EU and the US, and on the potential and limitations of existing approaches to measure the reshoring phenomenon. The main results and conclusions of this secondary study on similar and differentiating patterns of EU and US companies' reshoring activities can be briefly summarized as follows.

Reshoring seems to be a more common phenomenon in the US than in most European countries. In 2013, more than 20\% of the surveyed executives of US companies were actively engaged in reshoring manufacturing, with more than half of executives planning or considering reshoring activities (Boston Consulting Group, 2012). In Europe, the average share of companies active in reshoring at all manufacturing companies, 'adjusted' to a comparable timeframe of two years of activity, is around 4\% (Table 10.1). It varies significantly from around 1\% in Eastern European countries like Romania and Bulgaria to over 3\% in large industrial countries like Germany and the UK, $4 \%$ in Nordic countries like Denmark and Finland, around 6\% in Belgium and France, and up to $9 \%$ in Sweden and Ireland. However, it is very difficult to compare these figures, as they originate from different timeframes (from two to eight years) and, in the case of US surveys, even include companies that are only considering reshoring activities or investing in (new) manufacturing capacities in the US instead of in an offshore country. Thus, comparisons of reshoring levels between different countries need to be interpreted with great care. 
Table 10.1 'Adjusted' shares of companies active in reshoring for selected European countries

\begin{tabular}{lccc}
\hline Country & $\begin{array}{l}\text { Share of } \\
\text { companies } \\
\text { active in } \\
\text { reshoring }\end{array}$ & $\begin{array}{l}\text { Timeframe (years } \\
\text { covered) }\end{array}$ & $\begin{array}{c}\text { 'Adjusted' share of } \\
\text { companies active } \\
\text { in reshoring over a } \\
\text { two-year period }\end{array}$ \\
\hline Sweden & $27.0 \%$ & 6 & $9.0 \%$ \\
Ireland & $13.0 \%$ & 3 & $8.7 \%$ \\
Belgium & $9.5 \%$ & 3 & $6.3 \%$ \\
Slovakia & $9.0 \%$ & 3 & $6.0 \%$ \\
France & $14.0 \%$ & 5 & $5.6 \%$ \\
Denmark & $13.0 \%$ & 6 & $4.3 \%$ \\
Finland & $13.0 \%$ & 6 & $4.3 \%$ \\
DACH & $4.0 \%$ & 2 & $4.0 \%$ \\
Portugal & $6.0 \%$ & 3 & $4.0 \%$ \\
The Netherlands & $6.0 \%$ & 3 & $4.0 \%$ \\
Selected European countries & $\mathbf{4 . 0} \%$ & $\mathbf{2}$ & $\mathbf{4 . 0} \%$ \\
$\quad$ (EMS survey) & & & $3.3 \%$ \\
The UK & $13.0 \%$ & 8 & $3.0 \%$ \\
Germany & $3.0 \%$ & 2 & $2.3 \%$ \\
Estonia & $3.5 \%$ & 3 & $1.3 \%$ \\
Lithuania & $2.0 \%$ & 3 & $1.3 \%$ \\
Bulgaria & $2.0 \%$ & 3 & $0.7 \%$ \\
Romania & $1.0 \%$ & 3 & \\
\hline
\end{tabular}

Note: Source countries for reshoring by US companies are mostly China and other Asian countries, while for European companies, Western and in particular Eastern European countries are most important. However, China and India have also become more important as source countries for European companies' reshoring activities over time.

\subsection{The region of Veneto in Italy}

\subsubsection{Veneto and its manufacturing industry}

The Veneto region is located in the north-east of Italy and has for decades been the heartland of Italian manufacturing, hosting a variety of industries that emerged in the post-Second World War period; it has been part of the so-called Third Italy (Bagnasco, 1977). Much has been written on the Third Italy, especially in relation to it being characterized by the presence of a large number of industrial districts (Becattini et al.,2014), which flourished in the 1970s and 1980s and some of which are still present today. In Veneto, three main factors favoured the growth of industrial districts: (i) the export-oriented attitude of local firms; (ii) richness in local social capital; and (iii) a long period of domestic economic growth driven by the availability of a large labour pool thanks to internal migration from the southern regions in conjunction with a favourable monetary policy (Tattara and Anastasia, 2003; Bentivogli and Gallo, 2011). In the 1990s, the fast growth of the manufacturing sector and its export success took a new turn, with profound modifications in firms' division of labour (Giunta et al., 2012). Firms in labour-intensive sectors 
such as textiles and apparel and leather and footwear (TALF) started to delocalize the manufacturing functions to low labour-cost economies (Corò et al., 2013; Crestanello and Tattara, 2011; Dunford, 2006). Since small and medium-sized enterprises (SMEs) in industrial districts tended to be family-owned, their internationalization strategy tended to proceed mostly via offshored outsourcing and joint ventures rather than pure outward foreign direct investment (FDI) (Furlan et al., 2007). However, this offshoring pressure to seek cost-efficiency brought the region to a profound sense of 'crisis', ${ }^{1}$ and what was left of traditional manufacturing sectors presented a high degree of heterogeneity both within and across industrial districts (De Marchi et al., 2014). The 2008 Global Financial Crisis added an additional layer of problems mostly due to the long national recession that followed. By the end of 2017, after ten years of profound reorganization, manufacturing in the region still accounted for $97 \%$ of micro- and small firms and $55 \%$ of the active labour force. The fabricated metal products and TALF sectors are the largest in terms of the number of firms, accounting for $20 \%$ and $15 \%$ of the total number of firms in the region, respectively. ${ }^{2}$

\subsubsection{Evidence on reshoring in the region of Veneto}

There is evidence that previously offshored activities are being reshored back to Veneto. A few studies have started to look at the reshoring phenomenon in Italy at the national level (Kinkel et al., 2017), within industrial districts (Bettiol et al., 2017) and as a marketing strategy (Grappi et al., 2015). These studies agree the Veneto region has the highest percentage of firms that have adopted a reshoring strategy.

This section aims to shed further light on the specifics of the reshoring phenomenon in the Veneto region. By combining several sources such as local newspapers, microdata from the Union Chamber of Veneto and analysis of financial reports, we have compiled a list of 311 companies that have adopted reshoring strategies. From this data set we have extracted key information about firms' reshoring strategies. Firstly, we found that of these, one-third are small, one-third are medium-sized and one-third are large companies. Looking closer at sectorial composition, we found that TALF firms have been the most active, especially small-sized firms. On the other hand, in the Machinery and Equipment sector, medium-sized firms have more visibly adopted reshoring strategies. With a $6.4 \%$ growth rate in the first quarter of 2018, the industrial variation index for the Machinery \& Equipment sector was double the total for the regional economy $(3.2 \%)$ and the sector also saw investments finally overtake the 2010 level $^{3}$ (Callegari and Trevisanato, 2018). Secondly, in relation to the Machinery \& Equipment sector, analysing firms' financial statements, we found that reshoring strategies were adopted largely due to internal reorganization or through mergers and acquisition (M\&A) activities. Only a few companies in the TALF sectors adopted reshoring strategies to leverage 'Made in Italy' marketing brand value or to reduce lead time. From a careful analysis of financial statements, we found that very few firms reshored via plant closure, 
and the majority of firms decided to reshore a single product line or to invest in new facilities in Veneto to produce small volumes of high-value products. A third observation is that reshoring seems to co-exist with some offshoring, in that firms have 'brought back' only high-value and niche productions which can command the highest margins.

These observations were subsequently tested with a questionnaire. The survey was administered by the Union Chamber of Veneto in the last quarter of 2017 by adding one specific question on reshoring in the quarterly survey 'VenetoCongiuntura'. Firms were asked if they had in the period 2012-2017 done any of the following activities:

1. Closed a production site abroad and opened a new one in Veneto.

2. Reduced production in a foreign plant and increased production in a domestic plant.

3. Reduced the use of foreign suppliers and increased the use of domestic suppliers.

4. None of the above.

We defined a reshoring strategy as options 1-3 above. We had a sample of 1,200 firms, of which 26 declared as having adopted reshoring strategies. A first result confirms that reshoring in a strict sense (option 1 or 2) is small, with only five firms having selected option 1. It should be noted that these firms have more than 50 employees and operate in the intermediary goods sector. Firms' characteristics endorse the first and second observation, regarding dimension and sector. Of particular note is the finding that 21 firms selected option 3: of these, one is a large company, 16 are of medium size and the rest are micro-firms. In terms of sector composition, $42 \%$ of respondents were firms in heavy industries such as mechanics equipment and metal production, while $33 \%$ of respondents were in light industries (e.g. textile, leather and eyewear). Finally, of the 26 firms that adopted a reshoring strategy, all of them engaged both in reshoring and offshoring strategies at the same time, which confirms that reshoring was adopted to bring back only high-value, top-end and niche productions.

\subsection{The region of Baden-Württemberg in Germany}

\subsubsection{Baden-Württemberg and its manufacturing industry}

Baden-Württemberg is one of the leading economic regions in Germany, with well-known global companies located there, such as Daimler, Bosch and SAP and with many SMEs which are competing successfully in international markets and creating the basis for industrial efficiency and excellence. Twothirds of all jobs, $80 \%$ of trainee positions and more than half of the revenues in Baden-Württemberg are provided by medium-sized companies.

In Baden-Württemberg, the manufacturing industry records a higher share of value added than in any other German state. In 2017, more than 34\% of gross 
value added was attributed to the manufacturing industry. Its macro-economic impact is even larger, as it is strongly inter-connected to industry-related services. In 2017, Baden-Württemberg's manufacturing industry counted 8,200 companies, whose 1.284 million employees generated sales of around $€ 360$ billion euros. The federal state's industrial sector has an international focus: the export ratio, measured as foreign sales at total sales, exceeded 55\% (2017).

Baden-Württemberg's manufacturing industry features three leading industries: mechanical engineering (25\% of employees and $22 \%$ of sales in the region, and a $64 \%$ export ratio), car manufacturing (18\% of employees, $29 \%$ of sales and a $72 \%$ export ratio), and electrical engineering and electronics $(13 \%$ of employees, $11 \%$ of sales and a $55 \%$ export ratio). Together they generate around two-thirds of total manufacturing industry revenues. Alongside these lead industries, the metal-processing industry is also a major element of BadenWürttemberg's industrial profile.

Of all federal states in Germany, Baden-Württemberg invests by far the most in research and development $(\mathrm{R} \& \mathrm{D})$, with a $4.9 \%$ share of $\mathrm{R} \& \mathrm{D}$ expenditures of GDP in 2016. Baden-Württemberg is also the number one region in Germany in terms of patents per capita, with 132 patent applications per 100,000 inhabitants in 2017. Universities, external research institutes (e.g. Max Planck and Fraunhofer) and transfer centres (e.g. Fraunhofer and Steinbeis) between the scientific and business communities are key components of its research infrastructure and successful technology transfer, particularly to SMEs.

\subsubsection{Reshoring and Industry 4.0 adoption in Baden-Württemberg}

In Germany, only 9\% of manufacturing companies offshored parts of their production abroad from 2013 to mid-2015. As will be shown in more detail in Chapter 11, this value is barely higher than the lowest level ever measured since the 1990s. Over the past 12 years, fewer and fewer German companies have reduced their domestic production capacities in favour of foreign locations. In the same timeframe from 2013 to mid-2015, about 3\% of German manufacturing companies engaged in the reshoring of foreign production capacities to Germany (Kinkel and Jäger, 2017). Hence, there is currently one reshoring company for every three offshoring companies. While this does not seem to be a major trend, it is nevertheless a relevant phenomenon.

We use data from the same data source, the EMS 2015 edition, to illustrate and describe the respective reshoring patterns in Baden-Württemberg. The EMS is a firm-level survey that investigates products, processes, services and organizational innovation in European manufacturing. EMS is organized by a consortium coordinated by the Fraunhofer Institute for Systems and Innovation Research (ISI). The survey addressed all manufacturing sectors (NACE Rev. 2 classes 10-33) with at least 20 employees.

The Baden-Württemberg subset of the EMS 2015 edition comprises data from a total of 244 randomly selected companies and provides a representative picture of the manufacturing sector in terms of size classes and sector structure. 
Of the surveyed companies, 38\% have less than 50 employees, 44\% have 50-249 employees and $18 \%$ have 250 or more employees. Around $24 \%$ of the companies belong to the metal processing industry (20\% in the parent population), $21 \%$ to mechanical engineering (18\% in the parent population) and $6 \%$ to car manufacturing ( $4 \%$ in the parent population). To further improve the representativeness of the results on offshoring and reshoring behaviour, data was weighted in terms of size classes and sectors.

From 2013 to mid-2015, 2\% of manufacturing companies in BadenWürttemberg have performed a reshoring of production capacities from abroad. This is a noticeable but not significantly lower level than the 3\% share in Germany as a whole. This lower level might be partly due to the high share of metal processing and mechanical engineering companies in BadenWürttemberg, which overall reported below-average reshoring ratios of $1.9 \%$ and $1.4 \%$, respectively. Another reason might be the very high international orientation of the manufacturing industry in Baden-Württemberg, which led to many early, market-driven and sustaining offshoring activities, as local customers could be served directly from foreign locations. This customerdriven approach might have provided a stronger 'glue' and stamina to stay at the foreign location than might have been the case for activities in low-wage locations with respective customers elsewhere.

At the same time, manufacturing companies in Baden-Württemberg show a superior level of adoption of digitization technologies in manufacturing (Industry 4.0). More companies use technologies from all three digital technology fields (digital management systems, wireless human-machine communication and cyber-physical-systems), qualifying them as advanced users (level 3) using the I4.0 readiness index described in Chapter 11. In BadenWürttemberg, 35\% of manufacturing companies belong to this advanced group, compared to only $27 \%$ of all German manufacturing companies. Conversely, only $16 \%$ of the manufacturing companies in Baden-Württemberg belong to the non-users (level 0) of digital technologies in manufacturing, compared to $23 \%$ of all German manufacturing companies. Overall, manufacturing companies in Baden-Württemberg on average seem to be more advanced in Industry 4.0 technology use and readiness. This is not surprising, given the innovation strength of the Baden-Württemberg industry and the high importance of Industry 4.0-related industries like car manufacturing or mechanical engineering.

However, this excellent 14.0 readiness index in Baden-Württemberg does not seem to translate into a superior reshoring ratio, as other factors seem to keep most foreign manufacturing activities at their locations. One reason might be that the argument of flexible production of individual products in local value chains might in this case work at least partly in favour of staying at the foreign location, as early on many companies from Baden-Württemberg successfully built up foreign factories close to local customers. Another factor might be that many Baden-Württemberg companies are acting as suppliers or equipment providers for large multi-national lead firms, mainly from the automotive sector. 


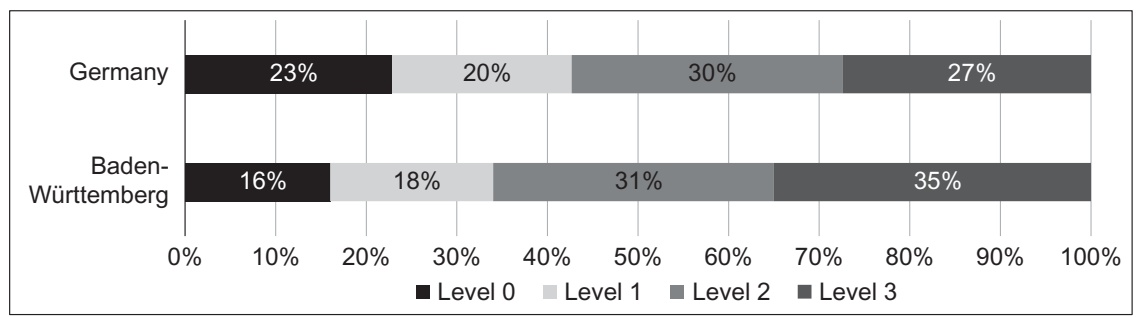

Figure 10.1 Industry 4.0 readiness index in the German and Baden-Württemberg manufacturing industry.

They have built up offshore locations to be close to their lead customers, and these close customer relations seem to provide an effective incentive to keep manufacturing activities of supplier companies at the foreign location, leading to a reduced likelihood of reshoring (Dachs et al., 2017).

\subsection{The region of the West Midlands in the UK}

\subsubsection{The West Midlands and its manufacturing industry}

The West Midlands is a UK region with a long tradition in the manufacturing sector. It comprises the Birmingham/Solihull area, the 'Black Country', Coventry, Stoke-on-Trent plus other shires (e.g. Staffordshire, Warwickshire and Worcestershire).The Midlands were the cradle of the First Industrial Revolution with the first large concentration of manufacturing firms in the metal, leather, glass and ceramics industries (MacNeill and Bailey, 2010). Thanks to the availability of labour and embedded know-how in metal materials, a cluster of automotive and aerospace industries flourished. However, since the 1960s, the manufacturing sector has gone through a severe industrial reorganization in the form of functional offshoring and increased foreign ownership (Donnelly et al., 2017), resulting in a significant loss of manufacturing jobs and firms. What was left, however, had to be high technology and positioned at the very top end producing high-value outputs (Bryson et al., 2013).

In recent years, the restructuring of manufacturing in the West Midlands saw a specialization in basic metals and metal products, and transportation and equipment.The specialization in those sectors fostered industries such as advanced manufacturing and engineering, and the aerospace and automotive industries (Eurostat, 2018). According to the West Midlands Industrial Strategy (2018), the automotive sector in the region counts 20 vehicle-manufacturing sites and 35 automotive original equipment manufacturers (OEMs), employs 46,000 people and generates $\mathcal{E}^{3} .2$ billion in gross value added (GVA). The major players in the cluster are Jaguar Land Rover,Aston Martin Lagonda and BMW. However, small and niche innovative companies such as the London Electric Vehicle Company 
(owned by the Chinese firm Geely) are flourishing. The region also hosts $10 \%$ of the British aerospace industry, with companies such as Rolls-Royce, UTC Aerospace System and Moog leading the cluster. The rail sector is linked to its historical metals production and remains important for the region, together with low carbon industries that are attracting innovative companies addressing the broader national sustainable agenda. The high-value medical technology and life science cluster is also crucial for the West Midlands economy through the application of AI, digital technologies and data analytics trials.

\subsubsection{Reshoring in the West Midlands}

In the last four years, the UK manufacturing sector steadily increased the number of employees up to 145,000 units in March 2018. However, the productivity index is reversing, suggesting that companies are hiring more people but not investing in new technologies. Some analysis confirms this, as onethird of the employment recorded in March 2018 was in low-tech activity (e.g. cutlery, radiators and screws). However, the transportation sector revealed signs of an opposite trend, employing highly skilled labour. In the automotive sector, there was an employment increase of 42,000 plus another 13,000 in other mobility-related sectors (e.g. aerospace, ship and train) up to 2018. Some commentators believe that this positive trend in manufacturing employment could be driven by a reshoring trend (Financial Times, 2018). ${ }^{4}$

Reshoring in the UK, especially in the West Midlands, has not been investigated in detail as yet. There have been no surveys on reshoring in West Midlands and official data do not capture the motives for bringing back manufacturing activity. However, De Propris and Bailey (2014) highlight the opportunities and challenges of reshoring in the automotive sector. Currently, the automotive sector is undergoing a disruptive technological transformation with the introduction of electric and driverless vehicles (Bailey, 2018). To unlock these challenges, Jaguar Land Rover for example invested \&3.7 million in a R\&D project called CORTEX in partnership with the University of Birmingham to further develop autonomous and connected cars (Jaguar Land Rover, 2018). The firm is also investing $£, 500$ million at its Whitley site in Coventry (Mullen, 2018), and in 2019 announced - despite job losses - investment in electric drivetrain assembly at its i54 engine plant and battery assembly at a new plant at Hams Hall, near Birmingham, as well as electric vehicle manufacturing at Castle Bromwich. While Jaguar Land Rover has expanded its manufacturing sites in China and Slovakia, it is keen to stress that it is also investing in British manufacturing sites for those activities related to high-value manufacturing, demonstrating its goal to pursue a truly international strategy.

In the West Midlands, another case of home-shoring was Mondelezowned Cadbury. Mondelez has invested $£ 75$ million over the last few years in upgrading its manufacturing plant in Bourneville, Birmingham and 'brought home' the production of some Dairy Milk bars from Poland and Dairy Milk Tiffin and Dairy Milk Oreo from Germany (Daily Telegraph, 2017). The limited 
production run of Dairy Milk Tiffin in the summer of 2016 became permanent in the summer of 2017, leveraging a consumer trend for nostalgic products (Mintel, 2018).

In the broader Midlands region (including the East Midlands), the textile and fashion industries are also historically significant. Lead firms in these sectors highlighted speed and flexibility as key drivers for offering 'fast-fashion' products, as well as the value of premium British-based brands able to leverage the authenticity of a 'Made in the UK' label. In Leicester, the fashion and textile industries in 2017 employed 9,500 people in 1,480 businesses. Further exogenous factors such as currency fluctuation and/or Brexit could further trigger a reshoring of production in the area. Business opportunities suggest that businesses in this sector should invest in technical textiles, composite and intermediate textile goods in order to satisfy valuable niche markets (Focus, 2017). The city of Leicester is the second-largest hub of fashion and textiles in the UK; some concerns have been raised about some instances of 'modern slavery' in some of its firms (Just-Style, 2018) and this could be a problem as sourcing is increasingly scrutinized by ethically conscious consumers; major retailers such as Asos and New Look expect the highest standards in order to decide to locate in the UK and in particular to reshore production to Leicester.

\subsection{Challenges in adopting a reshoring strategy in the EU}

Adopting a reshoring strategy is an intense and costly effort, whether a company decides to bring home production home either by opening a plant or by home-sourcing. The first implies heavy investment, while the second requires establishing trust with domestic suppliers, and a vibrant local supply chain (Bailey and De Propris, 2014). In particular, a common challenge faced by firms in adopting a reshoring strategy is the availability of skills and a competent workforce. In particular, high-skilled manufacturing roles are predominant in driving a reshoring strategy both in Veneto (Italy) and in the West Midlands (UK). For example, it took an Italian firm four years to upgrade its workforce internally with competent engineers and to reorganize its supply chain for more flexible production. ${ }^{5}$ In the West Midlands case, Jaguar Land Rover is investing $£, 100$ million a year into its JLR Academy, which has already upskilled 7,000 master-educated employees since 2010. ${ }^{6}$ In contrast to these two European regions, the Baden-Württemberg region does not suffer from a lack of technological skills of its workforce, due to its superior commitment to I4.0. However, specialists with corresponding digital skills (e.g. software development, data analysis and IT design) have become very scarce in the meantime. This shortage of skilled workers is a central challenge, especially for SMEs. Thus, as highlighted previously, the adoption of I4.0 technology in BadenWürttemberg companies is rarely translated into a reshoring strategy, but it is fundamental for the prosperity of the region as an important value-adding node embedded in GVCs. This last point is key for German firms, as their competitiveness is also driven by their participation in GVCs and therefore 
highly dependent on the lead firm's strategy. Many Baden-Württemberg companies are suppliers or equipment providers for large multi-national lead firms, mainly in the automotive sector, as shown above. They have to adopt advanced manufacturing and I4.0 technologies to be able to participate in these highly competitive value chains. They also need to build up offshore locations to be close to their lead customers' foreign factories. As noted, these close customer relations of supplier companies seem to provide an effective incentive to keep their manufacturing activities at the foreign location and to reduce the likelihood of reshoring (Dachs et al., 2017).

\subsection{Reshoring in the US}

\subsubsection{Offshoring and the momentum for bringing manufacturing back to the US}

Offshoring to China and other low-cost countries has caused the loss of about five million US manufacturing jobs over 20 years, has helped contribute to worker wage erosion and has had a negative effect on workers and the economy across America. Local communities have lost approximately $27 \%$ of their manufacturing workforce since 2000 . About $63 \%$ of the job losses are due to the offshoring of jobs. ${ }^{7}$ During the 2012 US presidential election, both Barack Obama (Democrat) and Mitt Romney (Republican) were blaming the sluggish economy on the outsourcing of US manufacturing to China.This rhetoric gave rise to serious executive conversations about the possibility of bringing manufacturing back to the US, if economically feasible, and for patriotic reasons, termed 'Economic Patriotism' by the Reshoring Institute. ${ }^{8}$ Beginning in 2012, reshoring and manufacturing expansion (those companies that decide to expand domestically instead of moving overseas) have enjoyed steady growth. This growth can be attributed to several factors:

- intellectual property theft concerns in China;

- $\quad$ rising Chinese wages for high-labour-content manufacturing;

- low energy costs in the US;

- introduction of automation such as $3 \mathrm{D}$ printing, robotics and advanced machine tools;

- $\quad$ reduction of latency in deliveries to US consumers;

- lower corporate tax rates (2017 reduction to $21 \%$ );

- lower tax rates for repatriation of overseas funds (2017 reduction to 15\%);

- relaxation of environmental regulations;

- consumer preference for goods made in the US.

During this same period, individual states offered significant local tax and other incentives such as training credits and infrastructure development to attract and keep manufacturers in their state. In some cases, state and local governments offered free property, data services and cash incentives to attract manufacturers. This is because manufacturing has an economic magnifier effect on local 
economies, promising new jobs and a greater tax base. For every $\$ 1.00$ spent in manufacturing, another $\$ 1.89$ is added to the US economy. That is the highest multiplier effect of any economic sector. In addition, for every one worker in manufacturing, there are another four employees hired elsewhere (National Association of Manufacturers). ${ }^{9}$

In 2017, the average manufacturing worker in the US earned $\$ 84,832$ annually, including pay and benefits. The average worker in all non-farm industries earned $\$ 66,847$. Looking specifically at wages, the average manufacturing worker earned more than $\$ 27$ per hour, according to the latest figures, not including benefits. ${ }^{10}$ These numbers put manufacturing workers squarely in the American middle class.

Taking a more informed and analytical approach to global manufacturing strategies and the cost of overseas production, American executives started to evaluate the possibility of bringing manufacturing home. In addition, American politicians began campaigning heavily on a 'jobs platform'. The momentum for this kind of informed analysis has grown over the past ten years, especially since the election of a Republican government - the party most favoured by American manufacturers for its policies on reducing taxes and eliminating environmental regulations.

For the first time in decades, more manufacturing jobs are returning to the US than are going offshore. Reshoring, plus foreign direct investment (FDI) surged in 2017. Manufacturing job announcements reached 171,000, up 50\% from 2016 and a remarkable 2,800\% from 2010. This brings the total number of manufacturing jobs brought to the US from offshore to over 576,000 since the manufacturing employment low of 2010. The 171,000 reshoring and FDI job announcements equal $90 \%$ of the 189,000 total manufacturing jobs added in $2017 .{ }^{11}$

The resurgence of US manufacturing and other jobs has been on a steady incline since the Great Recession of 2008-2010. Job growth rates climbed under the Obama Administration and the Trump Administration. However, enthusiasm for manufacturing is typically greater under Republican administrations. Coupled with tax rate restructuring, manufacturing is experiencing a positive rebirth and outlook in America.

\subsubsection{Selected case studies}

\section{GE Appliances}

GE Appliances provides an interesting reshoring example. In the 1990s, the CEO of GE, Jack Welsh, shut down much of GE's domestic appliance manufacturing, moving operations mostly to China. Even Asian appliance manufacturers and OEMs such as Samsung established primary manufacturing in China. This was done to leverage very low labour costs, low operating costs and the resulting increased profit margins. For GE, the manufacture of traditional water heaters was well suited to low-cost Chinese manufacturing to supply the US market and the burgeoning Chinese consumer market. But when Jeff Immelt 
became CEO in 2002, he challenged GE engineers to develop new products and technologies. One of the newest products was a heat-on-demand water heater called Geo-spring. The primary market for the Geo-spring was the US, due to its expensive price tag.

GE manufacturing engineers worked with design engineers to automate a very efficient production line that minimized labour and was cost-efficient. Lean manufacturing was added to Six Sigma programmes to keep quality high and costs low. GE then reopened manufacturing in Louisville, Kentucky at GE Appliance Park. In addition, GE worked with local labour unions for wage concessions and eventually rehired 4,000 workers for several new production lines. The GE Appliance division was later sold to Haier Appliances, a Chinese company, for $\$ 5.4$ billion in 2016. Haier now operates the Appliance Park facility. ${ }^{12}$

\section{iRT Wheels: technology for elite cyclists}

The use of advanced technology in manufacturing can reduce labour requirements and cost, improve quality and reduce supply chain latency. One example is iRT Wheels in Pasadena, California. CEO Ray Asante is an engineer by training and a former competitive cyclist. He began manufacturing and selling wheel hubs for elite cyclists in the early 2000s. Initially iRT Wheels designed the hubs in California, then ordered wheel hub prototypes from Taiwan at a cost of $\$ 7,000-\$ 10,000$, plus $\$ 5,000-\$ 10,000$ in duty, taxes and shipping fees to be delivered within 60-90 days. If the prototype was not correct, the process would have to be repeated, making new moulds, with more costs and time delay. Prototypes were sent back to California for adjustments, then sent back to Taiwan for manufacture.

In 2013, iRT Wheels purchased a 3D printer and started printing the prototypes and hubs in California. This process reduced per-unit costs, improved quality and allowed for the delivery of new hubs to elite cyclists within 48 hours. Rush orders can be delivered in 24 hours. In the competitive cycling world, this is a remarkable competitive advantage. This move to $3 \mathrm{D}$ printing saved the iRT Wheels $\$ 100,000$ over two years and significantly improved customer service.

\section{Use of Foreign Trade Zones: Lam Research, Silicon Valley}

The introduction of technology is important to the overall cost factors in making reshoring decisions, but it is not the only factor. Process and strategy can also be important decision factors. For example, the use of a Foreign Trade Zone allows for in-zone manufacturing, assembly, manipulation or storage. No customs duty is changed on the goods in a Zone until they are removed from the Zone and formally imported into the US. If the goods are subsequently exported form the Zone, they are not imported or taxed in the US.

Lam Research, a $\$ 14$ billion manufacturer of semiconductor equipment in Silicon Valley, uses Foreign Trade Zones extensively as part of its product 
and global logistics strategy. Parts from worldwide suppliers are brought into multiple Silicon Valley Foreign Trade Zones, to be incorporated into finished products, combined with domestic parts and products, or warehoused as spares. This carefully controlled physical environment is considered 'outside US Customs Territory' and goods kept there are considered foreign and restricted.

Once an order from a Lam Research customer is received, the products ordered are assembled inside the designated Zone and are then either shipped to a foreign customer or imported to be sold domestically. Each customer order is highly configured and unique.

Use of the Lam Research FTZs keeps manufacturing jobs in the US, delays or avoids the payment of Customs duties, and creates hundreds of new jobs managing the Foreign Trade Zone warehouses and operations.

\section{Buy American}

According to a study by Consumer Reports magazine, eight out of ten American consumers say they would prefer to buy an American-made product than an imported one. In several studies conducted by Walmart, the world's largest retailer, and other consumer groups, over $60 \%$ of shoppers say they are willing to pay $10-15 \%$ more for items made in the US. ${ }^{13}$ These statistics are used to drive reshoring decisions based on economic factors. If a manufacturer can produce products that are no more than 15\% more expensive than similar foreign-made products, Americans will choose the US product.

In determining the economics of competitive manufacturing in the US, the Reshoring Institute uses the 15\% margin target to guide total cost of ownership (TCO) modelling. The TCO can help guide the executive decision to bring manufacturing home.

The decision to manufacture in America is therefore guided by three decision criteria:

1. Economic analysis including the total cost of ownership modelling and cost reduction through automation and process efficiencies.

2. Government support through state and local incentives and federal corporate tax cuts, and reduction of regulations regarding manufacturing.

3. Consumer Buying Preference for products made and labelled 'Made in the USA'.

\subsection{Conclusion}

The magnitude of reshoring depends on the sectoral and value chain composition of the firms in a territory, as a reshoring strategy is more likely to be implemented by companies pursuing an individual customer-oriented strategy in the domestic market. The main motivations for reshoring are different between the territories of the EU and the US, and to some degree also between different regions in the EU. Table 10.2 below shows the push and pull factors 
Table 10.2 Push and pull factors for reshoring in the EU and the US

\begin{tabular}{|c|c|c|}
\hline & $E U$ & $U S$ \\
\hline $\begin{array}{l}\text { Push } \\
\text { Factors }\end{array}$ & $\begin{array}{l}\text { Quality issues } \\
\text { Loss of flexibility } \\
\text { Delivery time } \\
\text { Transportation costs } \\
\text { Reduction of labour cost gaps } \\
\text { Total costs of sourcing }\end{array}$ & $\begin{array}{l}\text { Loss of know-how, intellectual } \\
\text { property theft } \\
\text { Reduction of labour cost gaps } \\
\text { Total costs of sourcing } \\
\text { Transportation costs } \\
\text { Costs of control } \\
\text { Delivery time } \\
\text { Quality issues }\end{array}$ \\
\hline $\begin{array}{l}\text { Pull } \\
\text { Factors }\end{array}$ & $\begin{array}{l}\text { 'Made in' preference } \\
\text { Proximity to lead firms } \\
\text { Investment in technology for } \\
\text { advanced manufacturing } \\
\text { Incentives for investment in } \\
\text { I } 4.0 \text { technologies }\end{array}$ & $\begin{array}{l}\text { Low energy costs (in the US) } \\
\text { Investment in automation technology } \\
\text { Vicinity of production to R\&D } \\
\text { Relaxation of environmental } \\
\text { regulations } \\
\text { Lower corporate tax rates and tax rates } \\
\text { for repatriation of overseas funds } \\
\text { 'Made in' preference } \\
\text { Feeling of patriotism }\end{array}$ \\
\hline
\end{tabular}

that trigger a reshoring strategy, differentiated by the EU and the US as home regions. Some factors are shared between the two territories, while others are related only to a single territory.

The most important push factors for reshoring activities of European manufacturing companies are quality issues, loss of flexibility and delivery time, transportation costs, the reduction of labour cost gaps and the total costs of sourcing. The most important pull factors are the 'Made in' reputation effect, the proximity to lead firms in the home country, and investments and incentives to implement advanced manufacturing and I4.0 technologies to make production at the home base more competitive. Innovation-related factors like the loss of know-how or the vicinity of production to R\&D are less important for reshoring of European companies in the regions studied here,${ }^{14}$ as are some other manufacturing costs such as energy costs.

In the US, different cost factors, like rising labour costs at the offshore country, the total costs of sourcing, transportation costs or the costs of control, represent some of the most important push factors for reshoring. Also, intellectual property theft concerns in the offshore country and the consequent loss of know-how are seen as a very important boost for reshoring activities. The most important pull factors for reshoring to the US are: low energy costs in the US; the introduction of automation technologies such as additive manufacturing, robotics or advanced machine tools; the vicinity of production to R\&D; lower corporate tax rates; and lower tax rates for the repatriation of overseas funds.

Overall, the narrowing cost levels between emerging and developed countries seem to be more important for US companies' than for European 
companies' reshoring activities. Conversely, quality issues and losses of flexibility and delivery time seem to be relatively more important for European companies. Also, the exploitation of the 'Made in' buying preference effect is a reshoring driver that seems to be more important for European than for US manufacturers.

In addition, policy plays a different role for supporting reshoring activities in the EU and the US. Reshoring in the US is more directly supported by policy makers, e.g. by lower corporate tax rates, state and local incentives or by direct pressure on US companies to produce and buy in their home country. The US federal government also enforces the Buy American Act of 1933, requiring US government agencies to always purchase products made in the US unless they are not made or available in the US (US Code 41 U.S.C. SS 8301-8305).

The US 232 and 301 import penalty tariffs have negative effects on the manufacturing performance of US companies, as they damage export strategies and make foreign imports of raw materials, parts and products simply more expensive. In the EU, reshoring activities are more indirectly supported by the focus of European industrial policies on more inclusive growth. Promising measures to potentially support reshoring activities indirectly without having to subsidise them directly could include, among others:

- $\quad$ supporting regional clusters and local value chains;

- $\quad$ supporting local demand for innovative and more sustainable solutions (e.g. public procurement and 'Made in' local value chains);

- $\quad$ supporting the development and adoption of smart production systems (e.g. I4.0, agile and individualized manufacturing, additive manufacturing);

- $\quad$ supporting the development of smart, data-driven services and business models for B2B;

- $\quad$ supporting the education, qualification and competence development of skilled personnel, and limiting bottlenecks in digital key competences.

Despite these differences in motivations and supporting policies, manufacturing reshoring is considered to be an important strategy to increase the value of the territory, both in the EU and in the US.

\section{Notes}

1 Between 2007 and 2012, Italy faced both the Global Financial Crisis and the European debt crisis.

2 Data on firms dimensions, employee numbers and sectors compositions have been provided by the Union of Chamber of Commerce of Veneto, December 2017.

3 Data from the Eurostat series 'Annual detailed enterprise statistic for industry' (NACE Rev, 2, B-E), 'Code sbs_na_ind_r2'.

4 However, a combination of a fall in sales in China, the decline in diesel sales and Brexit uncertainty led to around 1400 job losses at Jaguar Land Rover in 2018, with another $4000+$ job losses announced by the firm in early 2019 . 
52016 anonymous firm's Financial Statement.

62018 JLR Financial Statement.

7 US Department of Labor, Bureau of Labor Statistics, www.bls.gov/.

8 www.reshoringinstitute.org.

9 www.nam.org.

10 Bureau of Economic Analysis and Bureau of Labor Statistics, 2017 www.bls.gov.

11 Reshoring Initiative, www.reshorenow.org.

12 Reshoring Institute Case Studies, www.ReshoringInstitute.org.

13 See www.reshoringinstitute.org.

14 For a counter view on production and R\&D in Spanish manufacturing 'home sourcing' see Bailey et al. (2018).

\section{References}

Ancarani, A., Di Mauro, C., Fratocchi, L., Orzes, G. and Sartor, M. 2015. Prior to reshoring: a duration analysis of foreign manufacturing ventures. International Journal of Production Economics, 169, 141-155.

Bagnasco, A. 1977. Tre Italia. La Problematica Territoriale dello Sviluppo Economico Italiano. Bologna: il Mulino.

Bentivogli, C. and Gallo, M. 2011. Nord Est: metamorfosi di un modello. L'economia del Nord Est. Report of the Bank of Italy, pp. 16-67.

Bailey, D. 2018. Comment: we need more backing for West Mids manufacturers. Birmingham Post, 19 June, Available at: www.birminghampost.co.uk/business/ business-opinion/comment-need-more-backing-west-14802440.

Bailey, D. and De Propris, L. 2014. Manufacturing reshoring and its limits: the UK automotive case. Cambridge Journal of Regions, Economy and Society, 7(3), 379-395.

Bailey, D, Corradini, C, and De Propris, L. 2018. 'Home-sourcing' and closer value chains in mature economies: the case of Spanish manufacturing. Cambridge Journal of Economics, 42(6), 1567-1584, Available at: https://academic.oup.com/cje/advancearticle/doi/10.1093/cje/bey020/5067309.

Becattini, G., Bellandi, M. and De Propris, L. (eds). 2014. A Handbook of Industrial Districts. Cheltenham: Edward Elgar.

Bettiol, M., Burlina, C., Chiarvesio, M. and Di Maria, E. 2017. From delocalisation to backshoring? Evidence from Italian industrial districts. Investigaciones Regionales Journal of Regional Research, 39, 137-154.

Boston Consulting Group. 2011. Made in America, again. Why manufacturing will return to the US. Available at: www.bcg.com/documents/file84471.pdf.

Boston Consulting Group. 2012. Made in America, Again: U.S. Manufacturing Nears the Tipping Point. Boston: Boston Consulting Group.

Bryson, J.R., Clark, J. and Mulhall, R. 2013. The competitiveness and evolving geography of British manufacturing: where is manufacturing tied locally and how might this change. Future of Manufacturing Project: Evidence Paper, 3.

Callegari, F. and Trevisanato, A. 2018. VenetoCongiuntura I trimestre 2018. Slides Conference Press, 25 May. Available at: www.ven.camcom.it/userfiles/ID251 VER2018_slide_UCV_defver02.pdf.

Corò, G., Schenkel, M. and Volpe, M. 2013. International offshoring, local effects: an inquiry on Italian firms. Symphonya. Emerging Issues in Management, 2, 88-99. 
Crestanello, P. and Tattara, G. 2011. A global network and its local ties, in N. De Liso and R. Leoncini (eds), Internationalization, Technological Change and the Theory of the Firm. London, Routledge, pp. 239-258.

Dachs, B., Kinkel, S. and Jäger, A. 2017. Bringing it all back home? Backshoring of manufacturing activities and the diffusion of Industry 4.0. Proceedings of the 6th European Conference on Corporate RED and Innovation, Seville, Spain, 27-29 September.

Daily Telegraph. 2017. Cadbury comes home as Dairy Milk production set to return to UK. 7 April. Available at: www.telegraph.co.uk/news/2017/04/06/ cadburys-comes-home-dairy-milk-production-set-return-uk.

De Marchi,V., Lee, J. and Gereffi, G. 2014. Globalization, recession and the internationalization of industrial districts: experiences from the Italian gold jewellery industry. European Planning Studies, 22(4), 866-884.

Donnelly, T., Begley, J. and Collis, C. 2017. The West Midlands automotive industry: the road downhill. Business History, 59(1), 56-74.

Dunford, M. 2006. Industrial districts, magic circles, and the restructuring of the Italian textiles and clothing chain. Economic Geography, 82(1), 27-59.

Eurostat. 2018. Regional Innovation Monitor Plus, West Midlands. Available at: https:// ec.europa.eu/growth/tools-databases/regional-innovation-monitor/base-profile/ west-midlands.

Fel, F. and Griette, E. 2016. Determinants for French firms' reshoring decisions: a proposed typology. Proceedings of the $23^{\text {rd }}$ International Annual EurOMA Conference, Trondheim, Norway, 19-21 June.

Financial Times. 2018. Manufacturing enjoys longest period of jobs growth for 40 years. 13 September. Available at: www.ft.com/content/6e60e386-ab9a-11e8-89a1e5de165fa619.

Focus. 2017. Leicester and Leicestershire Enterprise Partnership Leicester Textiles/ Leicester Fashion Hub Study Composite Report. Available at: www.llep.org.uk/ wp-content/uploads/2017/05/Leicester-Fashion-Hub-Report-May-2017.pdf.

Fratocchi, L., Ancarani, A., Barbieri, P., Di Mauro, C., Nassimbeni, G., Sartor, M.,Vignoli, M. and Zanoni, A. 2016. Motivations of manufacturing reshoring: an interpretative framework. International Journal of Physical Distribution \& Logistics Management, 46(2), 98-127.

Fratocchi, L., Di Mauro, C., Barbieri, P., Nassimbeni, G. and Zanoni, A. 2014. When manufacturing moves back: concepts and questions. Journal of Purchasing \& Supply Management, 20(1), 54-59.

Furlan, A., Grandinetti, R. and Camuffo, A. 2007. How do subcontractors evolve? International Journal of Operations \& Production Management, 27(1), 69-89.

Giunta, A., Nifo, A. and Scalera, D. 2012. Subcontracting in Italian industry: labour division, firm growth and the north-south divide. Regional Studies, 46(8), 1067-1083.

Grappi, S., Romani, S. and Bagozzi, R.P. 2015. Consumer stakeholder responses to reshoring strategies. Journal of the Academy of Marketing Science, 43(4), 453-471.

Heikkilä, J. (ed.). 2017. Relocation of Nordic Manufacturing. Tampere: Tampere University of Technology.

Jaguar Land Rover. 2018. Land Rover is making all-terrain autonomy a reality. 30 March. Available at: https://media.jaguarlandrover.com/news/2018/05/land-rovermaking-all-terrain-autonomy-reality. 
Just-Style. 2018. UK manufacturing: a ticking time bomb or sourcing gold? Available at: www.just-style.com/analysis/uk-manufacturing-a-ticking-time-bomb-orsourcing-gold_id134105.aspx.

Kinkel, S. 2012. Trends in production relocation and back-shoring activities: changing patterns in the course of the global economic crisis. International Journal of Operations \& Production Management, 32(6), 696-720.

Kinkel, S. 2014. Future and impact of backshoring - some conclusions from 15 years of research on German practices. Journal of Purchasing \& Supply Management, 20(1), 63-65.

Kinkel, S., Dewanti R.T., Zimmermann P. and Coates, R. 2017. MAKERS Deliverable 4.1. Measuring reshoring trends in EU and the US. Available at: www.makers-rise. org/wp-content/uploads/2018/02/D4.1-Measuring-reshoring-trends-in-the-EUprotected.pdf.

Kinkel, S. and Jäger, A. 2017. Auslandsverlagerungen, Rückverlagerungen und Digitalisierungsverhalten in der deutschen Industrie. Trends und Auswirkungen für den Produktionsstandort Deutschland. Hochschule Karlsruhe: Technik und Wirtschaft.

Kinkel, S. and Maloca, S. 2009. Drivers and antecedents of manufacturing offshoring and backshoring: a German perspective. Journal of Purchasing E Supply Management, 15(3), 154-165.

Li, D., Godsell, J. and Karatzas, A. 2017. The current state of manufacturing reshoring in the UK. Proceedings of the $24^{\text {th }}$ International Annual EurOMA Conference, Edinburgh, 3-5 July.

MacNeill, S. and Bailey, D. 2010. Changing policies for the automotive industry in an 'old' industrial region: an open innovation model for the UK West Midlands? International Journal of Automotive Technology and Management, 10(2-3), 128-144.

Mintel, 2018. Report - chocolate confectionery - UK, May.

Mullen, E. 2018. Jaguar Land Rover gets approval for huge Coventry expansion. 19 June. Available at: www.coventrytelegraph.net/news/coventry-news/jaguar-landrover-coventry-whitley-14923641.

Rikama, S., Nielsen, M.E., Bøegh Nielsen, P. Alajääskö, P. and Roodhuijzen, A. 2013. International sourcing of business functions, Eurostat.

Tattara, G. and Anastasia, B. 2003. How was that the Veneto region became so rich? Time and causes of a recent success. MPRA Paper No. 18458.

Wan, L., Orzes, G., Sartor, M., Di Mauro, C. and Nassimbeni, G. 2017. Entry modes in reshoring strategies: an empirical analysis. Proceedings of the $24^{\text {th }}$ International Annual EurOMA Conference, Edinburgh, 3-5 July.

West Midlands Industrial Strategy, Consultation Document. 2018. West Midlands Combined Authority. Available at: www.wmca.org.uk/media/2627/west-midlandsindustrial-strategy.pdf. 